\title{
300 years of coastal salinization research in Germany - the Homann (1718) map of the Christmas Flood of 1717
}

\author{
Georg J. Houben ${ }^{1}$ \\ ${ }^{1}$ BGR, Hannover, Germany
}

\begin{abstract}
The Christmas Flood of 1717 was one of the most destructive storm floods in the North Sea region and affected large parts of the shores of Germany, the Netherlands and Germany (e.g. Jakubowski-Tiessen 1992). It occurred in the night from the $24^{\text {th }}$ to the $25^{\text {th }}$ of December 1717, when a strong northwesterly storm front pushed massive volumes of water into the funnel-shaped German Bight. Adding to the astronomical high tide occurring this night, water levels rose up to $4 \mathrm{~m}$ higher than the mean tidal high water mark. This lead to widespread overtopping and breaching of the dikes, which had been neglected in the preceding years due to extended periods of war and unrest. Since the event happened at night, the population was unable to react. About 9,000 people in Germany lost their lives and around 2,500 in the Netherlands. The small German town of Jever alone lost 1,700 people. In the village of Stollhamm, located on the peninsula of Butjadingen, which was exposed to the flood from two sides, 582 out of a population of 1,200 perished and only a third of the houses were not destroyed. In Eastern Frisia, 922 houses were completely destroyed and 1,672 damaged. In all of the affected regions in Germany, at least 3,000 houses were completely destroyed. Agriculture was severely affected by the salinization of large tracts of agricultural land and the loss of 2,300 horses, 9,500 cows, 2,800 sheep and 1,800 pigs was recorded in Eastern Frisia. In the following years, famines and epidemic plagues took a further toll on the population. Many people emigrated. It took several decades to reconstruct the dikes and to restore the livelihoods of the population.
\end{abstract}

The 1717 flood was described in publications such as the "The tearful Christmas joy of the Jever region. Or: Detailed news of the high water flood which inundated the governance of Jever during Christmas night 1717 and what damages it caused [...] (Ummen 1718) and the rather dramatically titled „New and improved war, murder, death, misery and hardship calendar for the year 1717 after the merciful holy birth of our Lord and Redeemer Jesus Christ. Which [...] also contains a detailed description of the terrible storms and the resulting almost supernatural water floods through which god's hand beset the countries at the North, Zuider and Baltic Sea on the holy Christmas Day 1717 [...], accompanied by a copper engraving clearly presenting this punishment by God." by Adelsheim (1719).

Floods in this region were (and still are) not uncommon and floods preceding the Christmas flood are well documented in historical documents. The 1717 flood, however, was the first that attracted the attention of cartographers. Only one year after the flood, a colored copperplate engraving map titled "Geographical presentation of the miserable water flood in Lower Germany, which on the $25^{\text {th }}$ of December 1717 AD, in the holy Christ-Night, with innumerable damages and losses of many thousands of humans, inundated a large part of the duchies of Holstein and Bremen, the shires of Oldenburg, Frisia, Groningen and North Holland" was published in Nuremberg (Homann 1718). It shows an outline of the flooded area (green shading). This is probably the first largely accurate map of a coastal inundation. The salinization of soil and groundwater is, however, not explicitly mentioned. The flooded zones in the Northern Netherlands are also shown in an insert map. 
The cartographer of the map was Johann Baptist Homann (March 20, 1664 in Oberkammlach - July 1, 1724 in Nuremberg). In 1702, he opened a publishing house in Nuremberg, Germany, specializing in the production and sale of maps. His company became a very influential publisher of maps, which were also renowned for their artistic quality. Consequently, Homann became a member of the Royal Academy of Sciences in Berlin in 1715 and cartographer at the imperial court in Vienna. The publishing house existed until 1848.

The size of the map is $58 \mathrm{~cm}$ by $47 \mathrm{~cm}$. The base map is probably much older and contains several errors. For example, the island of Juist is missing and the island of Nordstrand is shown in its shape prior to the 1634 Burchardi flood, which destroyed much of the island. Prints of the Homann map must have been sold in relatively high quantities during the $18^{\text {th }}$ century, since copies can still be found in several European archives and some are even up for sale on online platforms. An internet search easily yields access to digital copies.

Homann and his coworkers probably neither mapped the flood extent themselves in the field nor inspected the installations shown in the insert images. They probably relied on descriptions by third parties, such as the reports by Ummen (1718) and Adelsheim (1719), which contain sufficient details about which cities were struck. Homann then probably only connected these dots to arrive at his outline of the flooding. Although this resulted in some errors, the general outline of the flooded marsh area is largely correct.

The map is adorned by depictions of antique deities, such as Neptune with his trident, goddesses of wind (Boreas?) and allegorical mythical beings. The crowned female figure to the right could be Hammonia, a Latin personification of the city Hamburg (the figure is placed close to the location of the city on the map). The map contains two text frames, one of which describes the flood and some of its consequences (in German). There, Homann puts the number of casualties in Germany at 18,140. The other contains a more general description of the problems of coastal zones (in German), followed by some excerpts from the "Metamorphoses" of the Roman poet Ovid (Publius Ovidius Naso) in Latin. The latter describe floods caused by the wrath of the gods and cities that have sunk below sea level.

Some inserts show pictures of a breached dam, a bucket elevator used for the removal of salt water through sluices and a sluice door in a dam that closes itself when water comes from the seaward side but opens automatically when water drains from the landward side. The latter images are, however, not realistic, the elevator would not work in the form shown and the depicted dam is excessively steep. The extent of the flooding is also not exactly reproduced in all details. For example, the German Frisian Islands are shown in light colors, indicating that they were not flooded. However, it is a known fact that they were strongly affected by the Christmas flood. Homann himself mentions the flooding of some islands in the first text frame. The map contains a few curious details, e.g. the description of a ship, which, on its way to France, was washed onto land through a breached dam with its complete cargo, near the present-day town of Cuxhaven.

Up to this day, the region covered in the Homann (1718) map has to deal with the threat of inundations. Securing a sustainable water supply for the population is an ongoing challenge, since saline groundwater often occurs kilometers away from the coast. Although the Christmas flood was not the only one that inundated the North Sea coast, the Homann map of 1718 provides an invaluable resource for hydrogeologists trying to delineate the boundary 
between fresh, brackish and saline water in this coastal zone. It also helps to explain how and when the salinization of coastal groundwater took place.

\section{REFERENCES}

Adelsheim, P. 1719. Neuer und Verbesserter Kriegs-(,) Mord- und Tod-(,) Jammer- und NothCalender/ Auf das Jahr nach der gnadenreichen heiligen Geburt unsers Herrn und Heilands Jesu Christi M DCC XIX. In welchem Nebenst der Beschreibung des Gewitters/Erwehlungen/der Planeten Lauff und Gang/samt deroselben natürlichen Zuneigungen/ auch zu finden ist Eine ausführliche Beschreibung Der entsetzlichen Stürme/ und daher verursachten fast über natürlichhohen Wasser-Fluten/ womit GOttes Hand am H.(eiligen) Christ-Tag 1717, und den 25. Hornung (= Februar) 1718 die Länder an der Nord-(,) Süder- und Ost-See heimgesuchet, Nebst einem Kupfer /welcher diese Strafe Gottes deutlich vorstellet. Verlag Johann Andrea Endters sel. Sohn und Erben, Nuremberg.

Homann, J.B. 1718. Geographische Vorstellung der jämerlichen Wasser-Flutt in Nieder-Teutschland, welche den 25. Dec(ember) A(nn)o 1717, in der heiligen Christ-Nacht, mit unzählichen Schaden, und Verlust vieler tausend Menschen, einen großen theil derer Herzogth(ümer) Holstein und Bremen, die Grafsch(aft) Oldenburg, Frislandt, Gröningen und Nort-Holland überschwemmet hat. Nuremberg.

Jakubowski-Tiessen, M. 1992. Sturmflut 1717. Die Bewältigung einer Naturkatastrophe in der Frühen Neuzeit. Munich, Oldenbourg.

Ummen, C.J. 1718. Die Mit Thränen verknüpffte Weynachts-Freude Jeverlandes. Oder Eine ausführliche Nachricht der hohen Wasser-Fluht/ Wodurch die Herrschafft Jever in der Christ-Nacht 1717. überschwemmet/ und was dadurch für Schaden verursachet worden In gebundener Rede entworffen/ und mit weitläufftigen Anmerckungen erläutert von Conrad Joachim Ummen. 32 p., Bremen. (http://digital.lb-oldenburg.de/ihd/content/thumbview/242095)

Contact Information: Georg J. Houben, Federal Institute for Geosciences and Natural Resources (BGR), Stilleweg 2, 30655 Hannover, Germany, Phone: +49-511-6432373, Email:

georg.houben@bgr.de 